\title{
Analisis Konsolidasi Server dengan Virtualisasi Menggunakan Proxmox VE
}

\author{
I Gusti Ngurah Wikranta Arsa ${ }^{1}$, I Nyoman Rudy Hendrawan ${ }^{2}$ \\ ${ }^{1}$ Sistem Komputer, ${ }^{2}$ Sistem Informasi \\ Institut Teknologi dan Bisnis STIKOM Bali \\ Denpasar, Indonesia \\ e-mail: ${ }^{1}$ arsa@stikom-bali.ac.id, ${ }^{2}$ rudyhendrawan@stikom-bali.ac.id \\ Diajukan: 30 Maret 2020; Direvisi: 28 April 2020; Diterima: 30 April 2020
}

\begin{abstract}
Abstrak
Konsolidasi server adalah sebuah teknik yang digunakan untuk membangun beberapa server virtualisasi di dalam sebuah mesin fisik/server fisik. Perkembangan konsolidasi server dapat digunakan sebagai salah satu teknik yang dapat digunakan dalam mengimplementasikan penyediaan server cloud computing. Salah satu hypervisor atau sistem operasi yang menangani virtualisasi adalah Proxmox Masalah utama penelitian ini adalah pembentukan beberapa virtualisasi server pada sebuah server fisik menimbulkan peningkatan beban kinerja dari server. Masalah lainnya adalah seberapa besar peningkatan beban server ketika dibuat beberapa server virtual dan sejauh mana kinerja dari server virtual ataupun server fisik. Penelitian ini melihat sejauh mana CPU utilization, penggunaan memori, dan lama proses mesin server mengerjakan sebuah pekerjaan. Dari hasil pengujian didapat peningkatan penggunaan sumber daya server fisik yaitu penggunaan CPU sebesar 48,7\% dan peningkatan memori sebesar 8MB dalam keadaan hanya menjalankan virtual mesin. Peningkatan CPU utilization dari $1 \%$ menjadi $2 \%$ ketika mesin server dibuatkan 10 virtual mesin (virtual server) dalam keadaan idle dan peningkatan memori dari 376 MB menjadi 468 MB. Lama waktu proses kompresi mesin server biasa 33,354 detik, mesin server dengan satu virtual server 39,98 detik, dan satu server dengan 10 VM sebesar 108,532 detik.
\end{abstract}

Kata kunci: Konsolidasi, Server, Cloud computing, Virtualisasi.

\begin{abstract}
Server consolidation is a technique used to build multiple virtualization servers in a physical machine. The development of server consolidation can be used as one of the techniques that can be used in implementing the provision of cloud computing servers. One of the hypervisor or operating system that handles virtualization is Proxmox. The main problem of this research is the formation of multiple server virtualizations on a physical server which certainly has the problem of increasing the performance load of the server. The next question is how big is the increase in server load when multiple virtual servers are created and the extent of the performance of the virtual server or physical server. This study looks at the extent to which CPU utilization, memory usage, and the length of time the server machine is doing a job. From the test results obtained an increase in use of physical server resources namely CPU usage by $48.7 \%$ and an increase in memory of $8 \mathrm{MB}$ in a state of only running a virtual machine. Increased CPU utilization from $1 \%$ to $2 \%$ when the server machine created 10 virtual machines (virtual server) in an idle state and increased memory from $376 \mathrm{MB}$ to $468 \mathrm{MB}$. The length of time for a normal server machine compression process is 33.354 seconds, a server machine with one virtual server is 39.98 seconds, and one server with $10 \mathrm{VMs}$ is 108.532 seconds.
\end{abstract}

Keywords: Server, Consolidation, Cloud computing, Virtualization.

\section{Pendahuluan}

Konsolidasi server adalah teknik dalam membuat beberapa virtual mesin dalam sebuah server fisik dan dijadikan dalam sebuah layanan [1]. Konsolidasi dapat juga diartikan menyentralisasikan beban kerja yaitu beberapa server virtual sebagai layanan Infrastructure As A Service ke dalam sebuah server fisik yang bertujuan untuk menekan biaya. Konsolidasi server menjadi sebuah teknik yang dapat digunakan oleh penyedia layanan cloud untuk menerapkan virtualisasi mesin server dan sebagai referensi peneliti dalam meneliti migrasi virtual mesin untuk server konsolidasi secara mengkhusus [2]. Konsolidasi server dapat 
digunakan untuk meningkatkan efisiensi penggunaan sumber daya komputer dengan pengurangan jumlah server, di mana fungsi yang awalnya ditangani beberapa server khusus dapat ditangani oleh sebuah server dengan kapasitas yang tentunya lebih besar [3]. Server konsolidasi juga diusulkan untuk mengemas virtual mesin secara ketat untuk mengurangi penggunaan jumlah mesin fisik yang berjalan [4]

Penggunaan server konsolidasi bertujuan mengurangi pembiayaan server fisik dan memaksimalkan kinerja server fisik karena terbagi ke dalam beberapa server. Salah satu teknik dalam melakukan konsolidasi server salah adalah dengan menggunakan virtualisasi, di mana dilakukan dengan cara membangun beberapa server virtual dalam sebuah server fisik. Dengan demikian, beberapa virtual mesin dapat dikemas pada satu mesin fisik tunggal sehingga membiarkan mesin fisik berjalan dalam kondisi kerja yang lebih hemat energi. Teknik ini disebut konsolidasi server dan merupakan pendekatan yang efektif dan banyak digunakan untuk mengurangi konsumsi energi total di pusat data [5]. Konsolidasi server dapat menyebabkan penurunan kinerja pekerjaan yang signifikan karena lokasi bersama dan migrasi mesin virtual [6].

Penggunaan server virtualisasi tentunya memiliki masalah atau kelemahan, salah satunya adalah peningkatan beban kerja dari server fisik dikarenakan adanya hypervisor yang berjalan pada server yang berfungsi untuk membentuk virtual server yang independen. Kinerja server perlu diperhatikan sebagai referensi sejauh mana efektivitas dari konsolidasi server dengan teknik virtualisasi. Di mana konsolidasi server ini juga dapat digunakan sebagai dasar dalam pengembangan infrastruktur cloud khususnya dalam menyediakan infrastruktur atau komputasi.

Analisis konsolidasi server pada penelitian ini adalah lanjutan dari penelitian sebelumnya tentang arsitektur konsolidasi server yang di mana hasilnya adalah usulan server konsolidasi arsitektur yang dapat digunakan untuk menyediakan layanan infrastruktur komputasi awan, di mana diusulkan tiga layer yaitu infrastructure layer untuk perangkat server fisik, hypervisor layer yaitu layer dengan sistem operasi yang berjalan, dan aplication layer yang berisikan seluruh mesin virtual dan tentunya dapat diakses oleh pengguna layanan cloud [7].

Berdasarkan arsitektur tersebut dibuatlah pengujian dengan berlatar masalah bahwa pembentukan beberapa virtualisasi server pada sebuah server fisik menimbulkan peningkatan beban kerja dari server fisik. Selanjutnya adalah seberapa besar peningkatan beban server ketika dibuat beberapa server virtual serta sejauh mana kinerja dari server virtual ataupun server fisik. Untuk mengetahui masalah tersebut akan dilihat sejauh mana $C P U$ utilization, penggunaan memori, dan lama proses mesin server mengerjakan sebuah pekerjaan.

Pengujian kinerja perlu dilakukan untuk melihat sejauh mana server dapat melayani permintaan dan melakukan beban kerja. Kebijakan konsolidasi server yang baik harus memastikan Quality of Service (QoS) yang andal bersama dengan pengurangan konsumsi energi untuk pelaksanaan beban kerja [8]. Seperti dilakukan oleh [9] di mana fokus penelitiannya adalah prediksi kelas konsolidasi beban kerja CPU dalam kluster web server untuk penyediaan sumber daya server yang optimal di mana berfokus dalam menghasilkan prediksi (klasifikasi) konsolidasi beban kerja kluster server terbaik menggunakan ANN (Artificial Neural Network). Selain itu yang menjadi tantangan dalam server konsolidasi adalah teknik server konsolidasi untuk menurunkan konsumsi energi dari server dan menjaga pengembangan berkelanjutan pada sektor industri ataupun akademis [5]. Hal ini juga menjadi fokus utama penyedia data center, di mana konsumsi daya menjadi isu utama selain dari kinerja, salah satu teknik penghematan daya adalah konsolidasi CPU [10].

\section{Metode Penelitian}

Metode yang digunakan dalam penelitian ini dimulai dari tahap investigasi sampai dengan tahap analisis akhir yang dapat dilihat pada Gambar 1 .

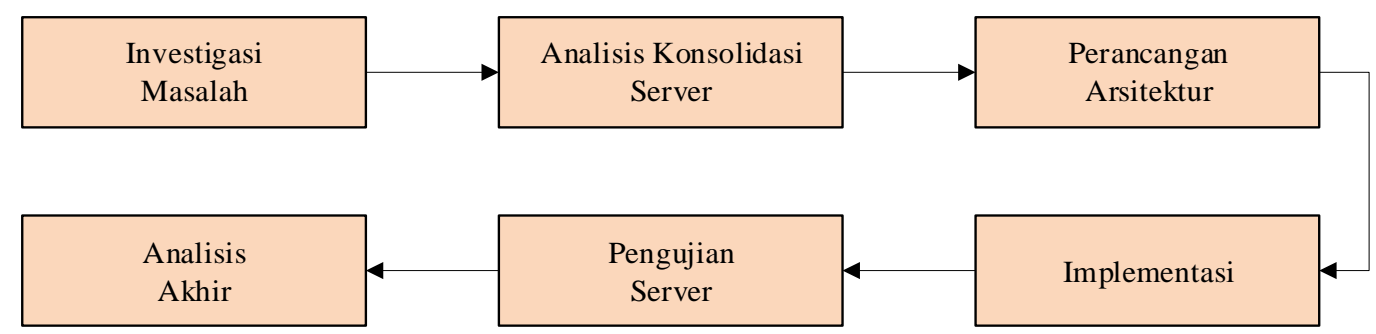

Gambar 1. Metode Penelitian [7]. 
Tahap investigasi masalah adalah tahap dalam menemukan masalah utama yang menjadi dasar dalam penelitian ini yaitu seberapa baik kinerja dari server dengan teknik server konsolidasi dalam melayani kebutuhan akan komputasi server, di mana komputasi yang dimaksud dalam hal ini adalah infrastruktur komputer. Selain itu bagaimana menerapkan konsolidasi server dalam penyedia layanan cloud menjadi masalah lainnya dalam penelitian ini.

Selanjutnya adalah analisis konsolidasi server, tahap ini dilakukan pendalaman materi tentang apa konsolidasi server, seperti apa aplikasi dan penerapan konsolidasi server, kelebihan dan kekurangan konsolidasi server dan beberapa studi literatur tentang penerapan konsolidasi server khususnya untuk sistem yang berbasis cloud computing.

Perancangan arsitektur adalah tahap selanjutnya dari penelitian ini. Pada tahap ini dilakukan perancangan arsitektur yang sesuai untuk sistem yang diujikan. Arsitektur yang digunakan bersumber dari beberapa referensi tentang arsitektur layanan infrastruktur cloud computing yang sudah pernah diusulkan. Dalam tahap ini diperhatikan juga implementasi nantinya dan tahap pengujian sistem dengan pemilihan arsitektur yang tepat.

Tahap keempat adalah implementasi, tahap ini dilakukan pengimplementasian dari sistem penyedia layanan cloud server atau cloud infrastruktur sesuai dengan arsitektur yang dipilih pada tahap sebelumnya. Proxmox Ve digunakan pada tahap implementasi ini dan sekaligus sebagai hypervisor yang digunakan untuk memonitor dan menciptakan virtual mesin. Proxmox VE berbasis Linux Debian dan bersifat open source. Selanjutnya dibuatkan server virtual yang berjalan pada sebuah server fisik. Pada implementasi akan dibuatkan sepuluh virtual mesin yang berjalan di atas server fisik.

Tahap selanjutnya adalah pengujian server konsolidasi, dalam tahap ini akan dilakukan pengujian kinerja server. Pada tahap ini dilakukan pengujian server dengan melakukan proses kompresi ke dalam mesin uji baik server virtual maupun server fisik. Tahap pertama akan dilihat persentase penggunaan $C P U$ dan Memori mesin fisik dan mesin virtual. Selanjutnya dibuatkan sepuluh server virtual yang nantinya disebut server konsolidasi dan di setiap server melakukan kompresi dan dilihat bagaimana kinerja masingmasing server dan rata-rata keseluruhan server virtual.

Tahap terakhir adalah analisis akhir, pada tahap ini dilakukan analisis dari hasil pengujian. Analisis akhir ini memberikan laporan berupa grafis hasil dari pengujian dan penjelasan kinerja yang dihasilkan dari server konsolidasi.

\section{Hasil dan Pembahasan}

Pada tahap implementasi, penelitian ini menggunakan dua buah server di mana kedua server diinstall sebuah sistem operasi Proxmox VE 2.3 yang selanjutnya kita sebut sebagai hypervisor. Selanjutnya mengonfigurasi satu server sebagai cloud controller dan satu server menjadi cloud node. Kedua server ini diisi dengan sistem operasi Proxmox VE 2.3. Kemudian kedua server dikonfigurasi menjadi cluster, sehingga cloud node dapat dikelola dalam satu buah server yaitu cloud controller. Gambar 2 adalah tampilan web manajemen cloud Proxmox.

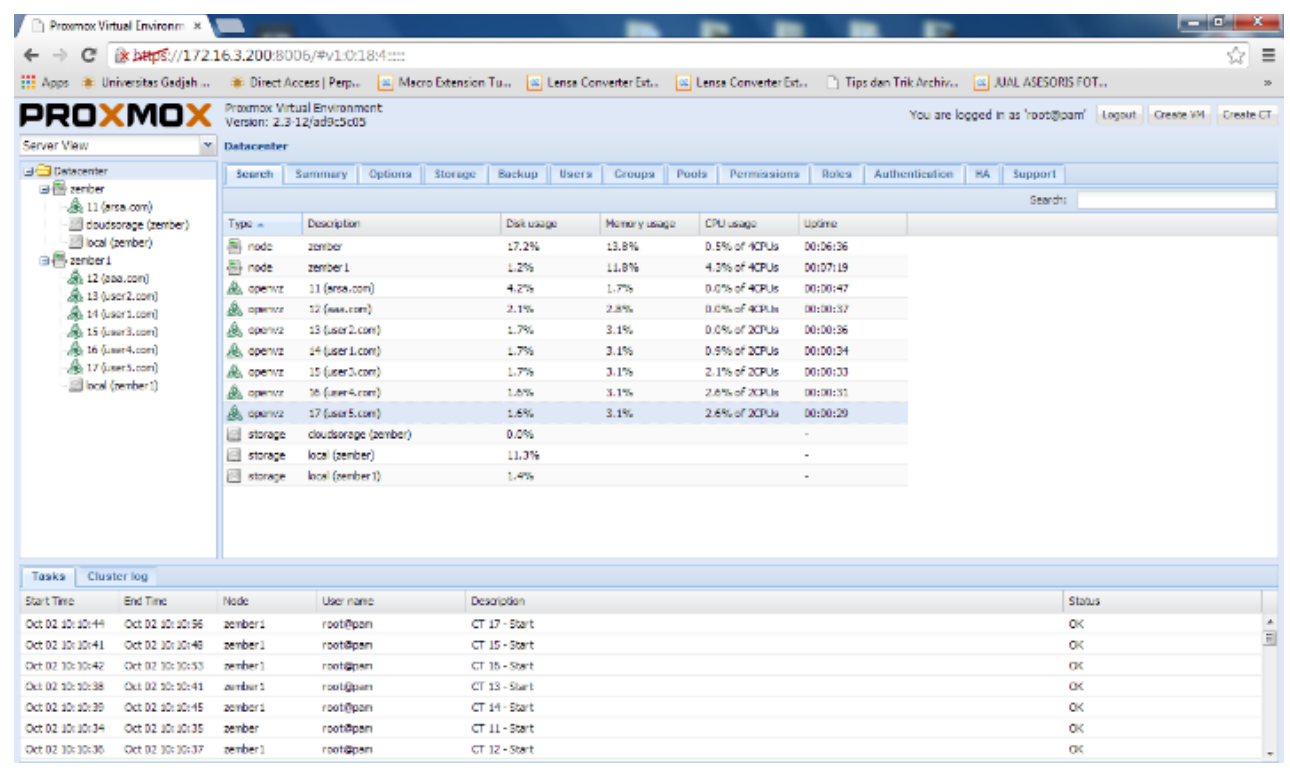

Gambar 2. Tampilan Proxmox di web browser. 
Gambar 2 memperlihatkan bagaimana user dapat leluasa mengelola seluruh mesin ada pada setiap node. Dalam hal ini server dengan nama "zember" bertindak sebagai server controller sekaligus menjadi sebuah node, sedangkan server "zember1" menjadi node. Dalam gambar juga diperlihatkan seluruh virtual mesin yang berjalan di atas kedua server fisik tersebut. Proxmox dapat mempermudah user dalam membuat dan memanajemen server fisik dan juga server virtual.

Pada Proxmox dapat dihasilkan beberapa server virtual ke dalam sebuah atau gabungan dari beberapa server. Proxmox dapat digunakan sebagai salah satu teknik konsolidasi server. Di mana dapat menghasilkan beberapa server virtual ke dalam sebuah pooling server. Selain itu Proxmox juga mampu menjadi sebuah perangkat lunak dalam mendukung terbentuknya grid computing dari sisi infrastruktur.

Gambar 3 memperlihatkan bagaimana server fisik cloud dapat dikonfigurasi dengan menggunakan SSH dari perangkat lunak PuTTY. Dari sini kita dapat mengonfigurasi server fisik, mengetahui jumlah VM yang berjalan pada mesin server tersebut. Proxmox pada dasarnya adalah sistem operasi cloud yang berbasis Debian. Jadi perintah dasar terminalnya menggunakan perintah dasar dari Debian. Gambar 3 juga memperlihatkan server node yang terhubung pada cluster dalam hal ini nama cluster-nya adalah "zemcluster".

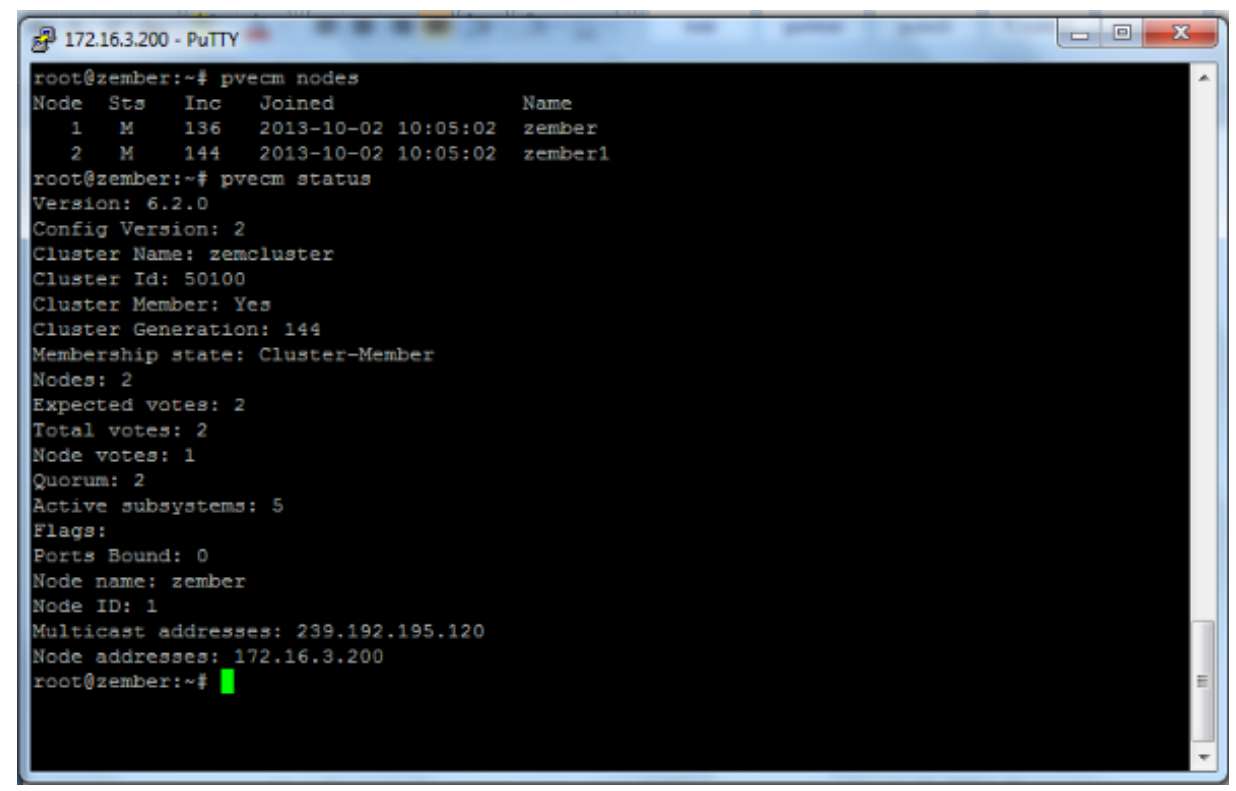

Gambar 3. Terminal server cloud controller.

Pada dasarnya servis ini dapat menunjang admin jaringan dalam pengelolaan server sebagai sebuah konsolidasi. Penelitian ini akan menggunakan skenario seperti di bawah ini:

1. Melakukan pembentukan server fisik dengan menggunakan Proxmox sebagai hypervisor sesuai dengan implementasi di atas.

2. Pembuatan server virtual pada pooling server (konsolidasi server).

3. Melakukan konfigurasi mesin virtual. Dalam skenario ini mesin virtual yang diterima akan dikonfigurasi menjadi sebuah server web. Pemilihan sebagai server web dimaksudkan untuk mempermudah dalam proses pengukuran (benchmarking) dalam penelitian ini.

4. Kompresi. Pada skenario ini akan dilakukan pengujian dengan bantuan tool kompresi. Skenario ini dilakukan di dalam server virtual dengan melakukan proses kompresi data.

5. Selanjutnya pada server cloud node akan dilakukan penambahan jumlah VM dan dilakukan kompresi pada masing-masing virtual mesin dengan jumlah virtual mesin dibuat sebanyak 10 VM.

6. Membandingkan satu server node dengan satu VM dengan satu server node dengan $10 \mathrm{VM}$.

Selanjutnya untuk melihat kinerja CPU dan memory ketika melakukan proses kompresi. Akan dilihat bagaimana penggunaan CPU pada mesin konvensional dengan satu mesin virtual dan melihat mesin fisik yang di atasnya berjalan $10 \mathrm{VM}$. Resource akan diamati dengan perintah htop pada setiap mesin. Gambar 4 memperlihatkan hasil penggunaan sumber daya mesin sebelum dan sesudah proses kompresi. Dalam gambar terlihat penggunaan CPU $1.3 \%$ dan memori $366 \mathrm{MB}$ pada saat mesin idle dan meningkat 
ketika dilakukan proses kompresi dengan kenaikan penggunaan CPU rata-rata sebesar 50\% dan memori sebesar $373 \mathrm{MB}$.
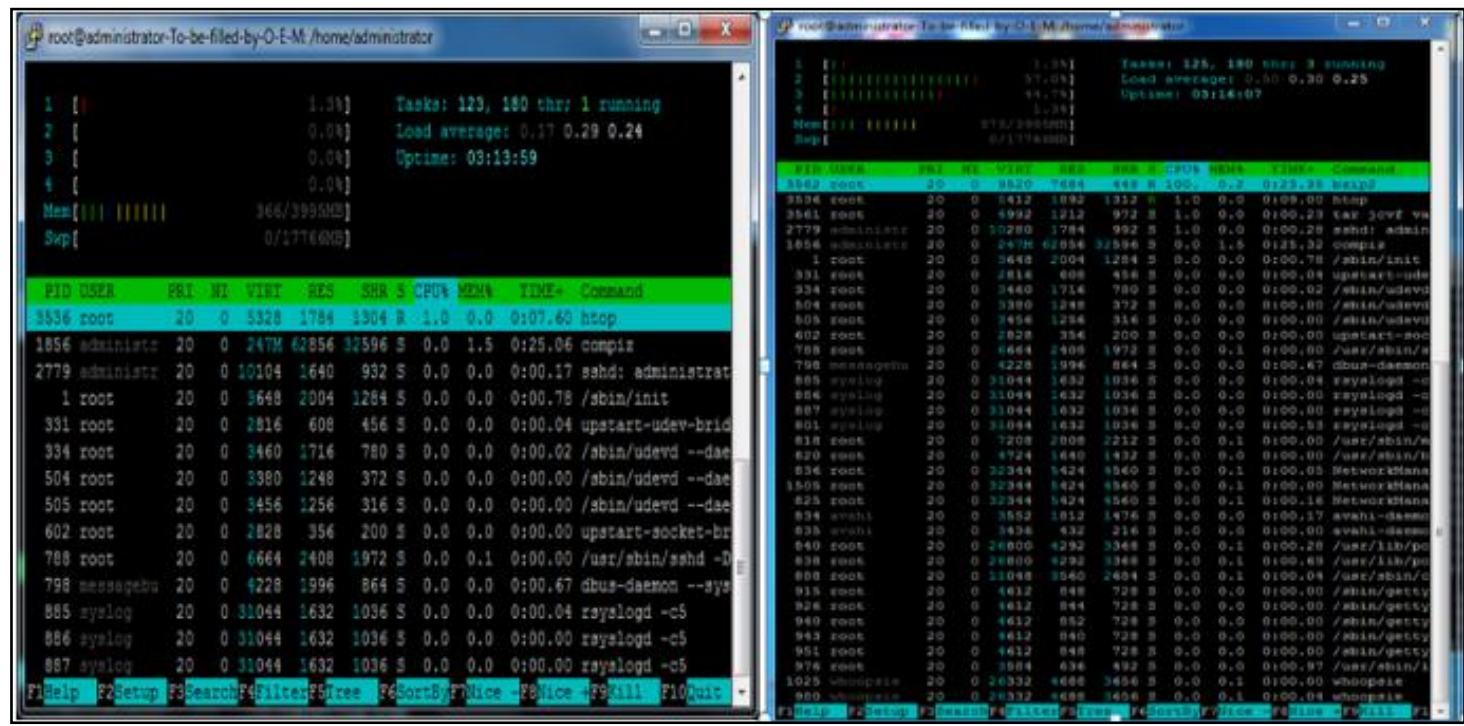

Gambar 4. Hasil resource mesin konvensional sebelum dan sesudah proses kompresi.

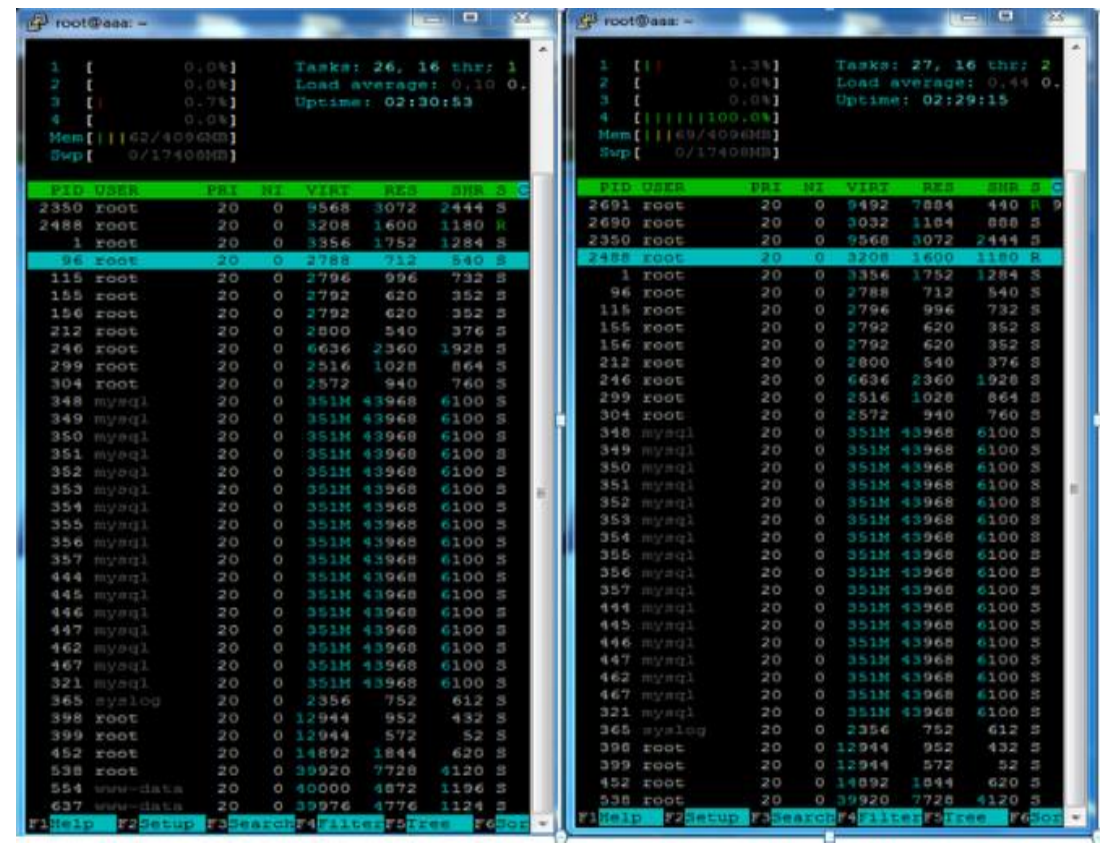

Gambar 5. Penggunaan sumber daya mesin virtual.

Pada Gambar 5 memperlihatkan penggunaan sumber daya mesin virtual sebelum proses kompresi dan sesudah proses kompresi. Dalam gambar penggunaan CPU resource mesin virtual pada saat idle ratarata $0.7 \%$ sedangkan penggunaan memori sebesar $62 \mathrm{MB}$. Selanjutnya ketika proses kompresi berlangsung penggunaan rata-rata CPU sebesar $100 \%$ pada core ke empat dan penggunaan memori meningkat menjadi $69 \mathrm{MB}$.

Gambar 6 memperlihatkan penggunaan resource dari sepuluh VM yang dijalankan pada mesin node. Terlihat rata-rata penggunaan CPU $0 \%$ dan penggunaan memori di setiap mesin sekitar $60 \mathrm{MB}$. 


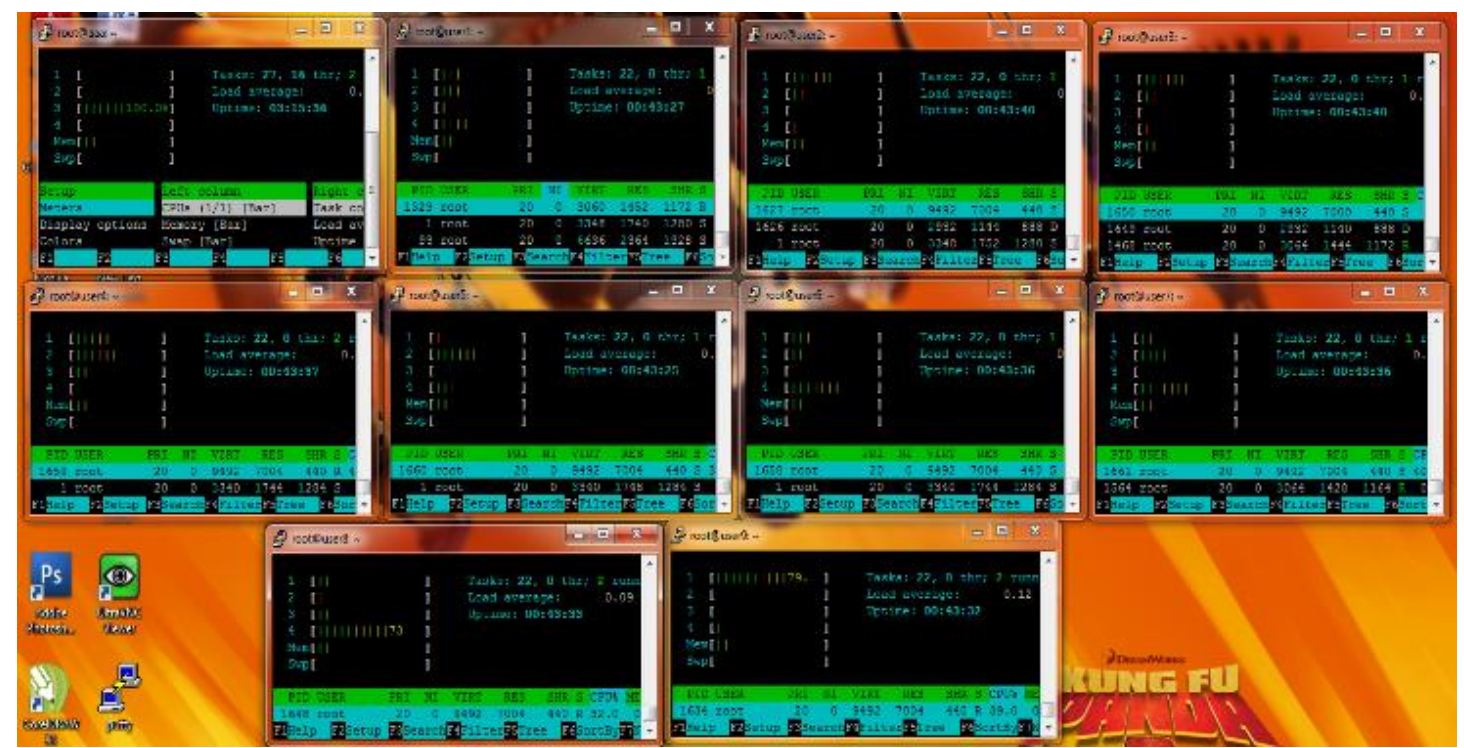

Gambar 6. Penggunaan resource sepuluh VM ketika melakukan proses kompresi.

Pada Gambar 6 memperlihatkan penggunaan resource kesepuluh VM pada saat melakukan proses kompresi secara bersamaan rata-rata penggunaan CPU lebih dari $50 \%$ dan penggunaan memori berkisar antara 60-65 MB.

Dari Hasil pengujian didapat kesimpulan pengujian seperti tertuang pada Tabel 1 dapat dilihat ada 3 skenario pengujian di mana menggunakan mekanisme kompresi di setiap server untuk mengetahui sejauh mana lama proses kompresi yang dibutuhkan. Besar data kompresi yang digunakan sebesar $249 \mathrm{MB}$. Di mana pertama diujikan pada server yang di dalamnya tanpa virtual mesin dengan waktu proses selama 33, 354 detik.

Tabel 1. Hasil Pengujian

\begin{tabular}{|c|c|c|}
\hline \multirow{2}{*}{ Skenario } & \multicolumn{2}{|r|}{ Service Instance } \\
\hline & $V M$ & Lama Waktu Pengujian (s) \\
\hline Kompresi 249 MB ( lama proses pada server tanpa VM ) & 0 & 33,354 \\
\hline Kompresi $249 \mathrm{MB}$ & 1 & 39,98 \\
\hline \multirow{10}{*}{$\begin{array}{l}\text { Kompresi } 249 \text { MB Kepada } \\
\text { seluruh VM Hampir Bersamaan }\end{array}$} & 1 & 116,082 \\
\hline & 2 & 108,921 \\
\hline & 3 & 108,769 \\
\hline & 4 & 102,409 \\
\hline & 5 & 105,693 \\
\hline & 6 & 111,195 \\
\hline & 7 & 110,045 \\
\hline & 8 & 107,205 \\
\hline & 9 & 108,370 \\
\hline & 10 & 106,672 \\
\hline Total Rata-rata $10 \mathrm{VM}$ & & 108,536 \\
\hline
\end{tabular}

Pada server yang dibuat dengan server virtual server, di mana pada satu server fisik hanya terdapat satu server virtual ketika dilakukan proses kompresi didapat kompresi dapat dikerjakan selama 39,98 detik. Terakhir pada server fisik dibuatkan sepuluh server virtual dan kesepuluh server virtual secara bersamaan melakukan kompresi dengan data yang sama didapat sesuai dengan Tabel 1 dengan rata-rata lama pengerjaan dengan 10 virtual mesin selama 108,536 detik. Terdapat lonjakan yang signifikan jika server virtual dibuat sebanyak 10 . Hal ini wajar dikarenakan jika ditotalkan proses yang dilakukan oleh server fisik sebenarnya mengerjakan 249MB x $10=2490 \mathrm{MB}$.

Terjadi peningkatan penggunaan sumber daya mesin server ketika melakukan kompresi sebesar 48,7 \% dan peningkatan penggunaan memori sebesar 7 MB dari 366 MB ke 373 MB. Sedangkan mesin virtual penggunaan CPU-nya dari 0,7 \% menjadi 100\% dengan penggunaan memori 62 MB menjadi 69 MB meningkat penggunaan memorinya sebesar 7 MB. Jika dilihat dari server fisik di mana server fisik dibuatkan atau dijalankan sebuah mesin virtual peningkatannya dimulai dari 1,3\% menjadi $100 \%$ pada 
core ke empat. Sedangkan memori dari 376 MB menjadi 384 MB terjadi peningkatan penggunaan memori sebesar $8 \mathrm{MB}$.

Penggunaan sumber daya pada server fisik dengan satu virtual mesin yang aktif sampai dengan sepuluh virtual mesin dalam keadaan idle penggunaan CPU meningkat $1 \%$, sedangkan memori meningkat sebesar 92 MB. Ketika proses kompresi dilakukan secara bersamaan pada kesepuluh virtual mesin penggunaan CPU menjadi maksimal 100\% di seluruh core CPU dan memori meningkat sebesar $178 \mathrm{MB}$. Sedangkan dilihat dari sisi virtual mesin ketika melakukan kompresi terjadi peningkatan penggunaan sebesar 50\% dan memori meningkat 5MB. Nilai resource ini didapatkan dari tool htop, sehingga keuntungan utama yang ditawarkan oleh penggunaan teknologi virtual adalah menjanjikan infrastruktur yang dapat diandalkan dan memungkinkan penggunaan resource yang maksimal dari sebuah server.

Dari tahap pengujian yang telah dilakukan dan analisis dengan beberapa penelitian sebelumnya didapat bahwa penggunaan hypervisor Proxmox VE dengan yang memiliki lisensi terbuka cukup andal digunakan di mana dilihat dari penggunaan CPU hypervisor dapat bekerja dengan maksimal di mana dapat dilihat dengan penggunaan mencapai $100 \%$ ketika proses kompresi dilakukan tentunya hal ini mengindikasikan Proxmox VE memaksimalkan sumber daya komputer secara maksimal begitu juga dengan penggunaan memori yang mengindikasikan Proxmox secara manajemen memori cukup andal.

\section{Kesimpulan}

Dari hasil analisa dan pengujian didapat kesimpulan sebagai berikut :

1. Terjadi peningkatan kinerja CPU utilization, memori, dan lama proses mengerjakan pekerjaan ketika dilakukan penambahan jumlah server (konsolidasi server) hal ini terjadi karena pembentukan server virtual pada server fisik yang tentunya menabahnya beban server fisik, namun perlu dilihat tingkat kewajaran dalam jumlah server virtual yang akan dibuat pada server fisik.

2. Dari hasil pengujian didapat peningkatan penggunaan resource mesin server sebelum dan sesudah melakukan proses yaitu CPU dari 1,3\% menjadi 50\% memori sebesar $376 \mathrm{MB}$ menjadi $384 \mathrm{MB}$ atau peningkatan $8 \mathrm{MB}$.

3. Peningkatan CPU utilization dari $1 \%$ menjadi $2 \%$ ketika mesin server dibuatkan 10 virtual mesin (virtual server) dalam keadaan idle dan peningkatan memori dari $376 \mathrm{MB}$ menjadi 468 MB.

4. Lama waktu proses kompresi mesin server biasa 33,354 detik, mesin server dengan satu virtual server 39,98 detik, dan satu server dengan 10 VM sebesar 108,532 detik.

\section{Daftar Pustaka}

[1] L. Tsai and W. Liao, Virtualized Cloud Data Center Networks: Issues in Resource Management. Taipei: Springer, 2016.

[2] B. Di Martino, A. Esposito, and A. Barbato, "High Performance Cloud : A MapReduce and GPGPU Based Hybrid Approach State of Art," Internet Distrib. Comput. Syst. IDCS 2014 Springer, vol. 8729, pp. 64-65, 2014.

[3] M. A. Nugroho and R. Katardi, "Analisis Kinerja Penerapan Container untuk Load Balancing Web Server pada Raspberry PI,” J. Ilm. Penelit. dan Pembelajaran Inform., vol. 01, pp. 7-15, 2016.

[4] S. Zhang, Z. Qian, Z. Luo, ... J. W.-I. T. on, and U. 2016, "Burstiness-aware resource reservation for server consolidation in computing clouds," ieeexplore.ieee.org, 2015.

[5] A. Varasteh and M. Goudarzi, "Server Consolidation Techniques in Virtualized Data Centers : A Survey," IEEE Syst. J., vol. 11, no. 2, pp. 772-783, 2017.

[6] K. Ye et al., "Profiling-based Workload Consolidation and Migration in Virtualized Data Centres," IEEE Trans. Parallel Distrib. Syst., vol. 26, no. 3, pp. 878-890, 2015.

[7] I. G. N. W. Arsa, "Arsitektur Konsolidasi Server dengan Virtualisasi untuk Penyedia Layanan Infrastruktur Cloud," J. Sist. dan Inform., vol. 14, no. 1, pp. 35-40, 2019.

[8] H. U. R. Qaiser, G. Shu, and A. W. Malik, "Utilization Driven Model for Server Consolidation in Cloud Data Centers," IEEE Access, vol. 8, pp. 1998-2007, 2020.

[9] A. S. Balantimuhe, S. H. Pramono, and H. Suyono, "Konsolidasi Beban Kerja Kluster Web server Dinamis dengan Pendekatan Backpropagation Neural Network," J. EECCIS, vol. 12, no. 2, pp. 7277, 2018.

[10] I. Hwang and M. Pedram, "A Comparative Study of the Effectiveness of CPU Consolidation Versus Dynamic Voltage and Frequency Scaling in a Virtualized," IEEE, pp. 1-14, 2015. 